\title{
Migratory flight and pre-diapause feeding of Coccinella septempunctata (Coleoptera) adults in agricultural and mountain ecosystems of Central Italy
}

\author{
Carlo RICCI, Luigi PONTI and Alvaro PIRES \\ Department of Arboriculture and Plant Protection, University of Perugia, Borgo XX Giugno, 06100 Perugia, Italy \\ e-mail: cricci@unipg.it
}

Key words. Coccinellidae, Coccinella septempunctata, foraging behaviour, aphids, pollens, fungi spores, crops, wild plants

\begin{abstract}
The research on pre-diapause feeding of C. septempunctata L. adults was carried out from 1998 to 2002 in the Tiber Valley, in the Botanical Garden of Perugia University, and in the Sibillini Mountains National Park (Central Italy). The species reproduces in spring feeding mostly on aphids infesting Graminaceae. In the second half of June, newly emerged adults have various migratory behaviours. Some of them remain in the valley while some leave the cereals and fly to other crops, where they feed both on 15 aphid species (e.g., Aphis gossypii Glov. on melon, Aphis fabae Scop. on sugarbeet), and also on pollens of wild plants such as Carduus nutans L., and fungi spores. However, most of the adults migrate to mountain pastures to find different food sources. During this migration, strong south-western storms often force the ladybirds to shelter in urban habitats. When the sunny weather returns again, due to the mistral (north-western wind), the adults continue the flight in swarms to mountain areas. In 1999, on Mt. Vettore $(2478 \mathrm{~m})$ we witnessed a "shower" of ladybirds, some of which hid in the turf. When reaching high altitude locations still covered with snow (Lake Pilato, $1940 \mathrm{~m}$, on Mt. Vettore), the adults, exhausted by the long flight, usually remain motionless on the snow. Due to the warming of the sun they sink to a depth of 5-6 cm, so that they remain trapped in the frozen snow during the night. At this site C. septempunctata was found together with Vibidia duodecimguttata (Poda) and Leptinotarsa decemlineata (Say). We investigated the gut content of adults from this location. After aggregation, the hungry adults disperse to flowering plants at lower elevations where they feed on 8 aphid species (e.g. broom aphid) and pollens of several plants (e.g., Laserpitium garganicum Tem., Centaurea rupestris L., Cachrys ferulacea L. The first mating was observed on broom. At "Pian Grande" location, adults were found in crop fields (lentil, mustard) and wild pastures (cornflower, gentian) mating and feeding on aphids, pollens, nectar and fungal spores. Haymaking forces ladybirds to move towards higher locations in search of food. Echinops ritro L., Eryngium amethystinum L., Carlina acaulis L., Cirsium eriophorum (L.), Galium verum L. and Euphorbia cyparissias L. were major food sources at $1800 \mathrm{~m}$ altitude. Gut content of C. septempunctata adults showed that pre-diapause diet consisted of aphids, pollen of Compositae and Umbelliferae, and spores of fungi (e.g., Alternaria spp., Cladosporium spp.). There was no statistical difference between the number of adults containing remains of aphids, fungal spores, and pollens. We found four significant correlations between the different food sources observed. In August some adults stopped feeding and in diapause condition sheltered under stones and among leaves or seed capsules of plants where they had fed. Others migrated to nearby woods and aggregated between juniper needles.
\end{abstract}

\section{INTRODUCTION}

Coccinella septempunctata L. is a common ladybird beetle of the Palearctic and Asian regions and has become established in the USA (Schaefer \& Dysart, 1988; Krafsur et al., 2005). C. septempunctata is an important aphidophagous species; a list of aphids preyed was reported by Hodek (1996). Some aphid species (e.g., Aphis spiraephaga F.P.M., Schizaphis graminum Rondani, Sitobion avenae F., Diuraphis noxia, Rhopalosiphum maidis Fitch, Acyrthosiphon pisum Harris) are very suitable for this ladybird (Kuznetsov, 1975; Obrycki \& Orr, 1990; Formusoh \& Wilde, 1993). The essential foods and foraging behaviour of $C$. septempunctata in spring during the reproductive period are well known (Hodek 1956, 1962; Iperti, 1965; Blackman, 1967; Kuznetsov, 1975; Mills, 1981; Honěk, 1982, 1985; Savoiskaya, 1983; Zhang, 1992; Ferran \& Dixon, 1993), but there is almost no data on summer diet, when the ladybird must accumulate energy reserves, in order to survive during dormancy (Hodek, 1996). Triltsch (1997) found that fungal spores and pollen were important food sources for prediapausing adults. In the Mediterranean area $C$. septem- punctata, usually, reproduces only once a year, feeding mostly on aphids infesting Graminaceae and broad bean.

The aim of this study was to clarify diet and foraging behaviour of $C$. septempunctata adults in pre-diapause in Central Italy.

\section{MATERIAL AND METHODS}

The research was conducted in 1998-2002 from mid-June to mid-September in crop fields, urban habitats and mountain pastures of central Italy. In the Tiber Valley $(200 \mathrm{~m})$ we surveyed fields of alfalfa, sugarbeet, sunflower, safflower, melon, maize and wild plants at field margins. Observations were also made in the Botanical Garden of Perugia University. Mountain habitats were located in the Sibillini Mountains National Park, where two sites were selected: the big plain named "Pian Grande" $(1250 \mathrm{~m})$ and Pilato Lake $(1940 \mathrm{~m})$, located on Mount Vettore $(2478 \mathrm{~m})$. Pian Grande is the second largest basin in Italy. It is a mosaic of cultivated fields and wild areas, known for the great diversity of plants (1500 species) flowering either together or one after another, between June and July. In this period the plain explodes in a fantastic variety of colours. The typical crops here are lentil, spelt, wheat, rye, sulla. The human activity is well integrated within this natural ecosystem. At the mountain site, Pilato Lake, only sparse plants are present. 

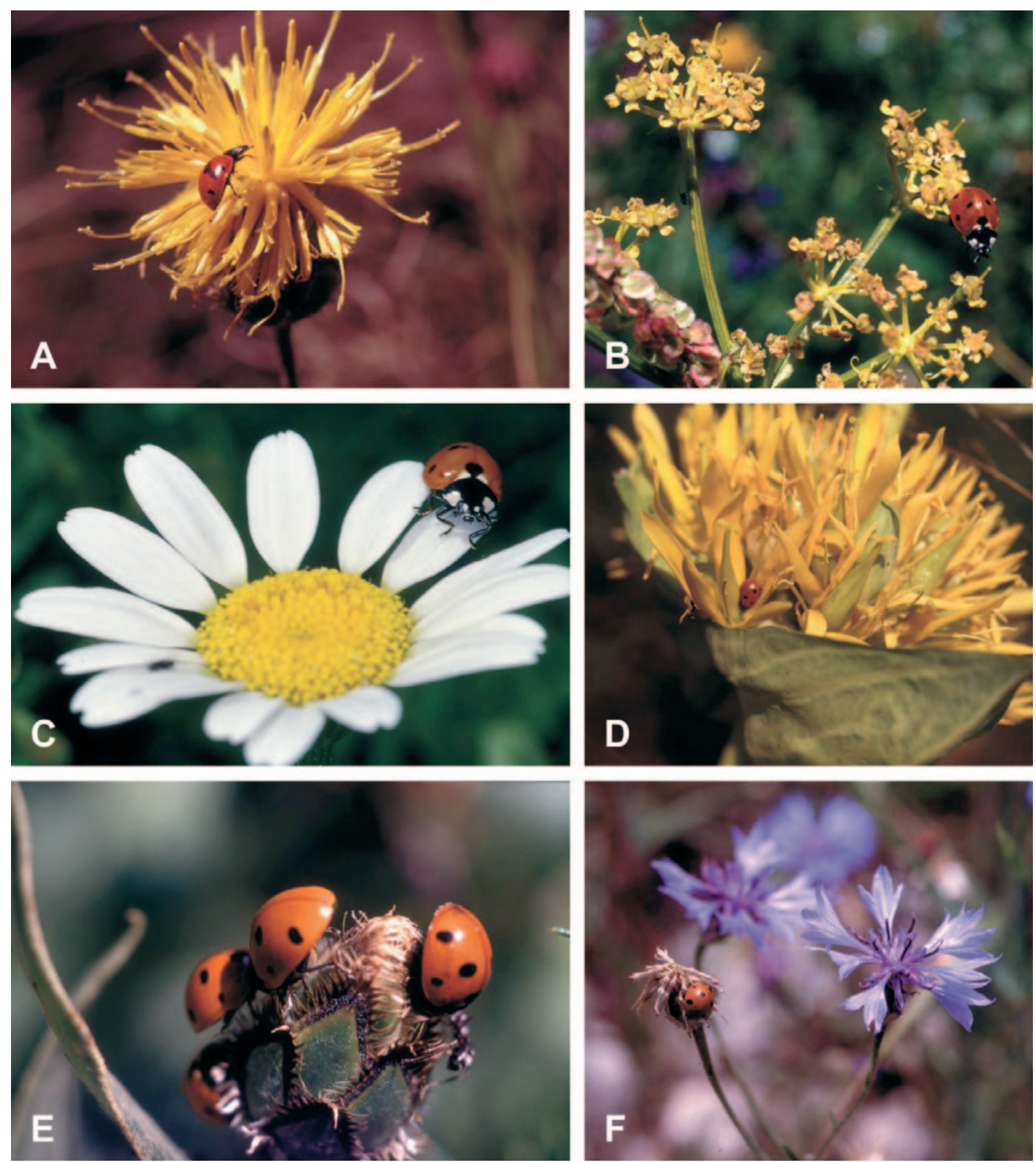

Fig. 1. Plants visited by Coccinella septempunctata adults in the summer. (A) Centaurea rupestris L.; (B) Cachrys ferulacea L.; (C) Leucanthemum vulgare L.; (D-E) Centaurea cyanus L.; (F) Gentiana lutea L.

In each study area, the dynamics of flowering plants (from low to high levels) and aphid populations were recorded. In the morning, between 10.00 a.m and 12.00 noon, visual observations on flowering plants were carried out to note the presence of $C$. septempunctata adults and their behaviour. The gut content was studied in adults collected randomly with D-Vac in 8 habitats (30 individuals/habitat). Two samples were taken from reproduction sites, at the end of May on alfalfa and beginning of June on wheat. From mid-June to mid-August the ladybirds were sampled on lentil fields with wild plants (e.g. Centaurea cyanus L.) and meadows with various plants (e.g. Gentiana lutea L.; Carduus nutans L.; Leucanthemum vulgare L.) of the Pian Grande area. Although the samples gathered are a subset of a wider collection they can be considered representative of seasonal patterns observed during the whole survey.

The influence of agricultural practices (e.g. harvesting) was also considered. The plants and aphids were identified.

Gut contents and feces of sampled adults were observed at the light microscope. Remains of aphids and other preys were noted in terms of presence or absence, whereas pollens and spores of 

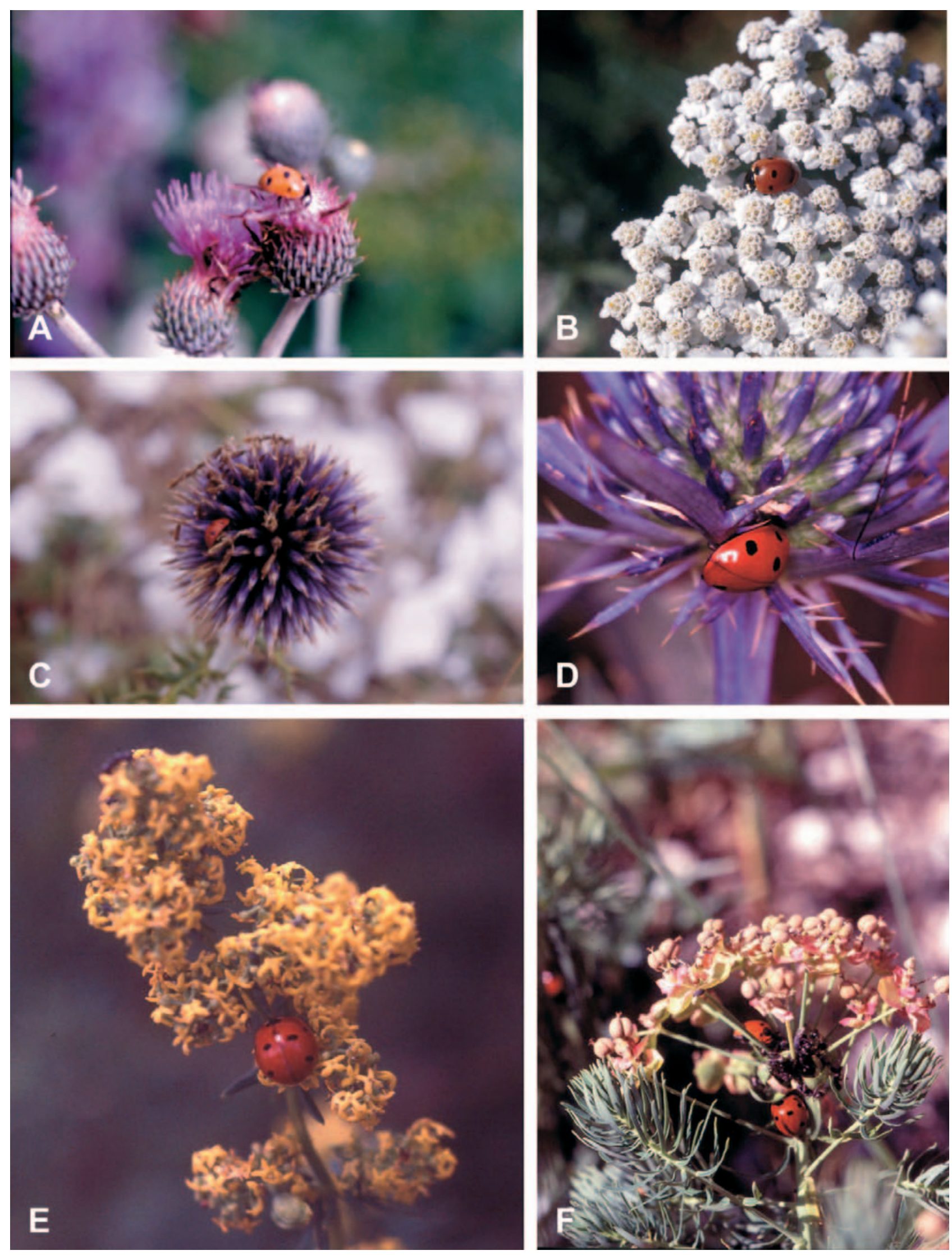

Fig. 2. Plant visited by Coccinella septempunctata adults in the summer. (A) Carduus nutans L.; (B) Achillea collina Bec.; (C) Echinops ritro L.; (D) Eryngium amethystinum L.; (E) Galium verum L.; (F) Euphorbia cyparissias L. 

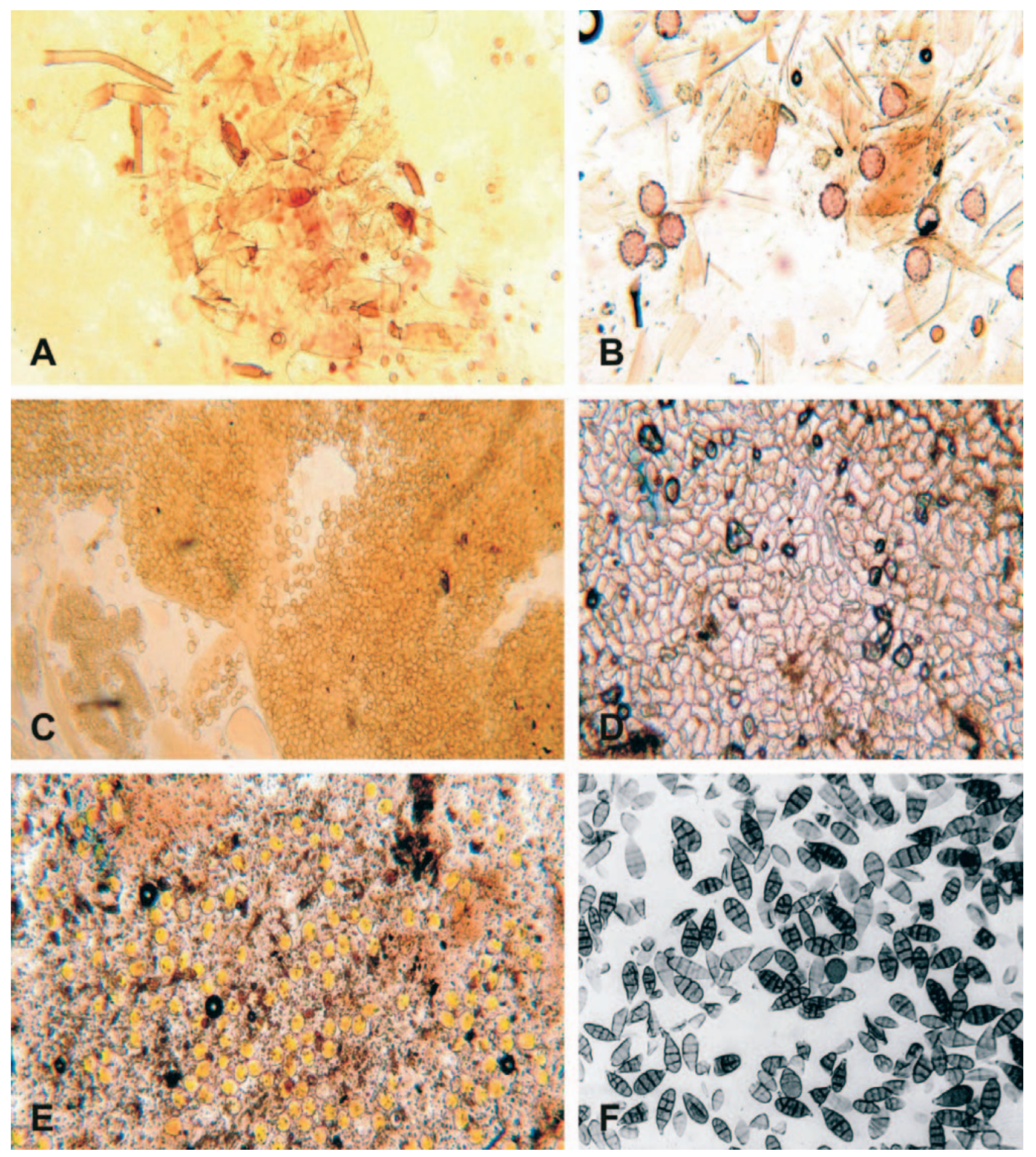

Fig. 3. Samples of gut content found in Coccinella septempunctata adults collected during the summer. (A) aphids with fungal spores; (B) aphids and Compositae pollens; (C) other Compositae pollens; (D) Umbelliferae pollens; (E) Puccinia spp. spores and unidentified material; (F) Alternaria spp. spores.

fungi were counted. Based on these observations, we tested for positive and negative associations between the presence of foods from different sources in the digestive tract of individual C. septempunctata. Since some foods were recorded as presence or absence while others were counted, a common currency was needed to explore these associations. The currency used was the number of individual coccinellids per sample with a particular food item in their gut. This number was used to compute correlation coefficients, which were therefore based on whether indi- vidual ladybirds did or did not have a particular food item in their gut. Using the same data aggregated in three categories (aphids, pollens and fungi) we also computed a Duncan's test to find overall trends in food preference in prediapausing C. septempunctata. 


\section{RESULTS}

\section{Behaviour of adults}

In Central Italy the new adults emerge from pupae about mid June. They remain in the breeding site (wheat and broad bean) and feed on aphids. When the wheat begins to mature, the aphid population drops drastically, so that ladybird adults leave this crop habitat to find new food. At this time we observed trivial flights, aggregation and dispersal. Some adults remain in the Tiber Valley agroecosystems, where they continue to feed on about 15 aphid species, some of which are pests (e.g., Aphis fabae on sugarbeet, Aphis gossypii on melon). The ladybirds also feed on pollen of Compositae and Umbelliferae, nectar and spores of fungi. Pesticide applications to control A. fabae on sugarbeet and A. gossypii on melon, negatively affected $C$. septempunctata populations. Most of the ladybirds actually fly to mountain pastures to forage and find hibernation sites.

Strong south-western storms often force the adults to shelter in urban habitats. In mid June 1999 high densities of $C$. septempunctata were observed in Perugia, both in the Botanical Garden and in green recreational areas near the city. Likewise, great aggregations were observed along the Adriatic Riviera. In these areas the ladybirds prey on the following aphids: Aphis cytisorum Hartig on Spartium junceum L., Macrosiphoniella artemisiae (B.d.F.) on Artemisia vulgaris L., Microlophium carnosum (Buckton) and Aphis urticata Gmelin on Urtica dioica L. They also feed on pollen of ornamental plants, where aphid populations were already low.

When the mistral (north-western wind) makes the sun shine again, the adults fly in swarms to mountain pastures. In 1999, at the beginning of July, in a meadow on Mt. Vettore at $1800 \mathrm{~m}$, we witnessed a "shower" of ladybirds. As soon as they reached ground, some individuals hid in the turf. Some of the adults could reach even higher altitudes, still covered by snow. Exhausted by the long flight, these ladybirds usually remain motionless on stones, herbaceous plants, and also snow. The weight and the warmth of the sun sink the adults that land on snow to a depth of 5-6 cm. Remaining trapped in the frozen snow during the night, $30 \%$ of them die. Within a few days after arrival, these large masses of $C$. septempunctata adults disperse as the adults fly to flowering plants in natural pastures and mountain crops.

In July 20, 1999 at Pilato Lake, C. septempunctata adults were found together with Vibidia duodecimguttata (Poda) (a mycophagous coccinellid species) and the chrysomelid Leptinotarsa decemlineata (Say). Dissecting 30 C. septempunctata individuals from this locality, we found that $15 \%$ of them had an empty gut but remarkable fat reserves, while $85 \%$ had food remains and few fat reserves. About $15 \%$ were parasitized by Dinocampus coccinellae (Schrank) larvae $(5 \%$ of the larvae were mature, the rest were immature). The gut content was composed of aphid remains, pollens, and fungal spores. Whereas there were only fungi spores in the $V$. duodecimguttata guts.
At the same time at $800 \mathrm{~m}$ ladybirds were found feeding on pollens and 8 aphid species: A. cytisorum on $S$. junceum L., A. fabae on Centaurea sp., Macrosiphoniella usquertensis H.R.L. on Achillea millefolium L., Brachycaudus cardui L. on Carduus pycnocephalus L., Brachycaudus helichrysi (Kalt.) on Santolina sp., A. balloticola Szel. on Marrubium vulgare L., Uroleucon sonchi (L.) on Sonchus oleraceus L., Uromelan jaceae subsp. aeneus (H.R.L.) on Carduus nutans L. On this last plant we noted the first mating. After mating the ladybirds proceed with foraging, searching for new aphid infestations and flowering plants.

In meadows at $1000 \mathrm{~m}$ the first flowering plant (Laserpitium garganicum Ten.) provides about one week of food; the second (Centaurea rupestris L.) (Fig. 1a) provides food for further ten days; the third (Cachrys ferulacea L.) (Fig. 1b) gives ten additional days of pollen availability. In the Sibillini Mountains National Park, the ladybirds arrive at Pian Grande $(1250 \mathrm{~m})$ at the beginning of July, when the above described sequence of flowering plants is already in act. At this location, adults were found on crops (e.g., lentil with wild mustard and cornflower). In meadow they visited Leucanthemum vulgare L. (Fig. 1c), Centaurea cyanus L. (Fig. 1d,e), Gentiana lutea L. (Fig. 1f), C. nutans L. (Fig. 2a), Cirsium eriophorum L., Achillea collina Becker. (Fig. 2b), Heracleum sphondylium L.. These plants provide C. septempunctata with aphids, pollen, nectar, and fungal spores and also shelter to continue mating. On C. cyanus, ladybird adults were particularly attracted by extrafloral nectar, but they had to compete with ants and wasps. On C. nutans and C. eriophorum, we found as many as five ladybird adults aggregated on a head.

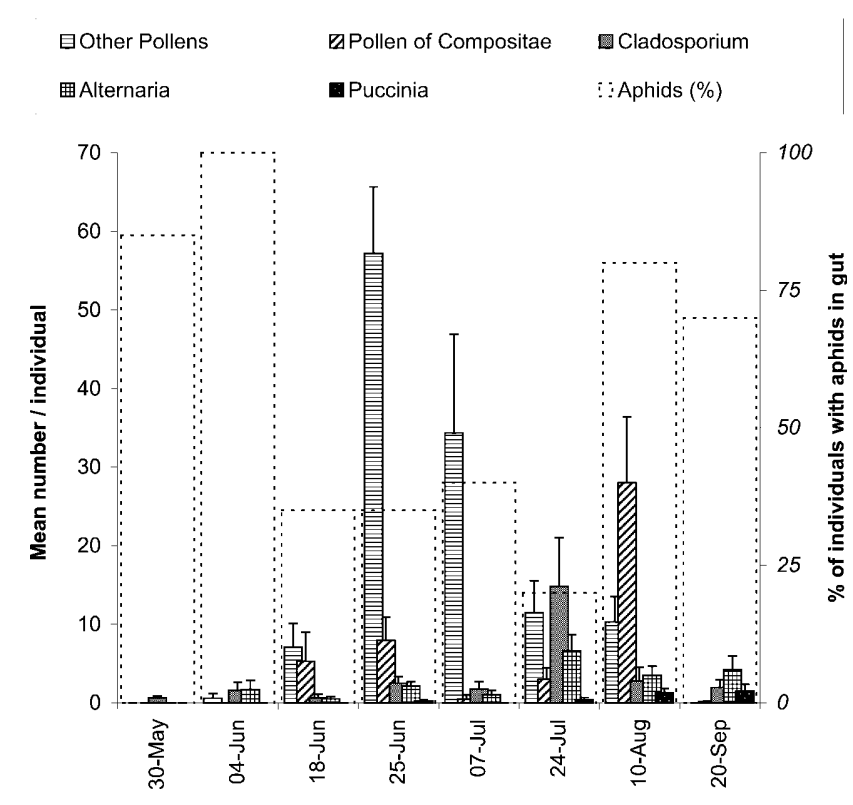

Fig. 4. Mean number ( \pm SE) of pollen grains and fungal spores remains found in the gut of an individual adult of Coccinella septempunctata L., compared to the percent of coccinellid adults with aphids in gut (dotted bars) on different dates in 2002. 

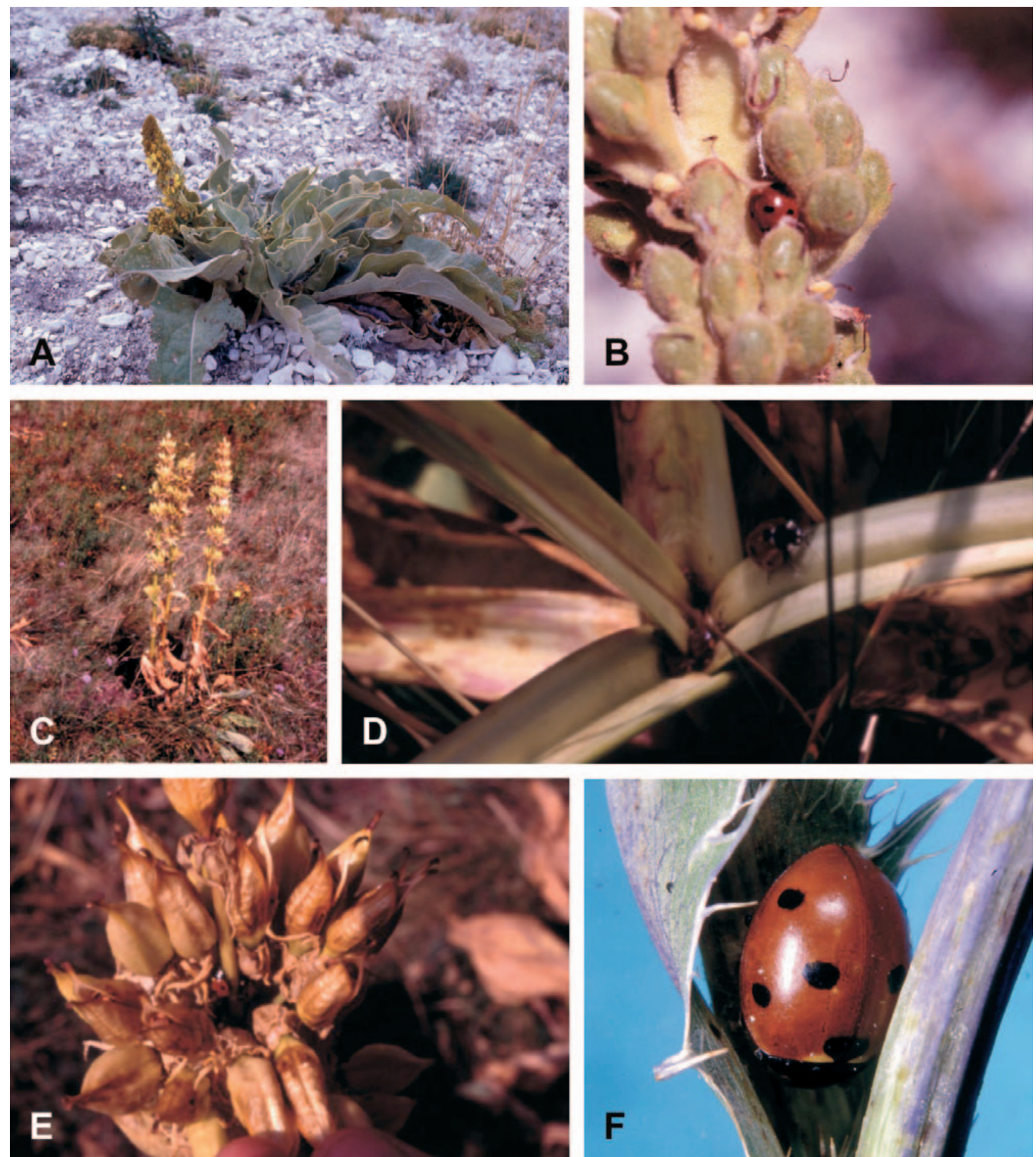

Fig. 5. Examples of plants used as refuge sites by Coccinella septempunctata adults. Verbascum thapsus L. plant (A) and seeds (B); Gentiana lutea L. plant (C), leaves sheath (D) and seeds (E); (F) Eryngium amethystinum L. leaf and stem.

In July in Pian Grande the sulla crop is gathered, then the meadow hay is cut and gathered, and the lentils are ready for harvesting, so the ladybirds fly to wild vegetation or move up to higher altitudes (up to $1800 \mathrm{~m}$ ) to search for other food sources. In these areas the adults were found on the following plants: Echinops ritro L. (Fig. 2c), Eryngium amethystinum L. (Fig. 2d), Carlina acaulis L., C. eriophorum, Galium verum L. (Fig. 2e) and Euphorbia cyparissias L. (Fig. 2f). On aphid infested
E. amethystinum and E. cyparissias mating ladybirds were often observed.

In August some adults stop their feeding and enter diapause. We found some of them under stones on mountains tops, others among the leaves or under the seed capsules of the plants where they had fed. Small groups of adults (3-4 specimens) together with earwigs (10-12 specimens) were found among the leaves of Verbascum thapsus L. (Fig. 5a), and single adults here and there 
TABLE 1. Correlation coefficients from May-September between numbers of Coccinella septempunctata adults per sample showing different food remains in their gut ( 8 samples, $\mathrm{n}=30$ per sample: ${ }^{*} \mathrm{P} \leq 0.05 ;{ }^{*} \mathrm{P} \leq 0.01$ ).

\begin{tabular}{lccccc}
\hline & Aphids & Pollen Compositae & Other pollens & Cladosporium & Alternaria \\
\hline Pollen of Compositae & 0.085 & & & & \\
Other pollens & -0.384 & $0.746^{*}$ & & & \\
Cladosporium & 0.034 & 0.550 & 0.312 & 0.575 & 0.661 \\
Alternaria & -0.455 & $0.730^{*}$ & $0.710^{*}$ & 0.626 & 0.345 \\
Puccinia & 0.218 & $0.829^{* *}$ & & & \\
\hline
\end{tabular}

among the seed capsules (Fig. 5b). On G. lutea (Fig. 5c) we found single adults between the sheath of the leaves and the stem (Fig. 5d), and small groups (2-3) among the seed capsules (Fig. 5e). On E. amethystinum, we found a single adult between the leaf and the stem (Fig. 5f).

\section{Gut content}

Analysis of the gut content showed that C. septempunctata diet includes aphids, pollen of various plants (mostly Compositae, Umbelliferae and Gentianaceae), and fungal spores (mostly Alternaria spp. and Puccinia spp.). Fig 3 shows some examples of gut contents: (A) aphids with fungal spores; (B) aphids and pollen of Compositae; (C) other pollen of Compositae; (D) pollen of Umbelliferae; (E) Puccinia sp. spores and unidentified material; (F) Alternaria sp. spores.

Fig. 4 gives the mean number per individual ladybird of pollens, fungi and \% aphids found in the gut. In the summer, these foods were always present in the gut. Statistical analysis did not show significant differences between the number of adults with remains of aphids, fungal spores, and pollens (Duncan's test, $\mathrm{P} \leq 0.01$ ). This is an indication that, although aphids are still an important food source, alternative food sources (Compositae pollen and fungi infesting these plants) play a key role in the foraging strategy of prediapausing C. septempunctata. Therefore, when available, they feed on non aphid and aphid food and when no aphids are available they feed on pollens and fungi.

In Table 1, we report correlation coefficients between percentages of $C$. septempunctata adults showing different food remains from May to September. Correlation coefficients confirm that aphids are still an essential food also for pre-diapausing adults in all habitats sampled, since there was no significant relation between aphids and other food sources. The pollen of Compositae showed a significant positive association with the spores of Puccinia sp., which is known to cause specific rust diseases in the Compositae (Ialongo et al., 1983). The significant positive association between the pollen of Compositae and the spores of Alternaria sp. is probably related to the well-known susceptibility of Compositae to Alternaria sp., which has indeed been investigated as a biological control agent of Compositae weeds (Andersen \& Lindow, 1985). The positive association between other pollens (mostly Umbelliferae) and the spores of Alternaria sp. may be related to the fact that Umbelliferae are known to be susceptible to these pathogens (Goidanich, 1964).

\section{CONCLUSIONS}

In central Italy, many adults of $C$. septempumctata in the summer continue to feed on aphids, pollens, nectar and fungal spores. Among the plants visited, Compositae, Umbelliferae and Gentianaceae were preferred. Pollen, nectar and fungal spores are necessary to accumulate energy reserves for overwintering. Since there is a succession of flowering plants, a continuous food supply is assured for the ladybirds.

The human activity (e.g., pesticide applications in agroecosystems of the Tiber Valley) reduces the populations of both aphids and ladybirds. In mountain areas other activities (e.g. harvesting, grazing by domestic animals) reduce the availability of plants and so C. septempunctata have to find other sites to feed. The ladybirds that stop foraging in August diapause both on the plants where they fed, using them as a refuge, and under rocks. Since the ladybirds migrate from different areas to the mountain habitats, where they mate, genetic variability is assured.

ACKNOWLEDGEMENTS. The authors would like to thank the following specialists: S. Barbagallo of Catania University for the identification of aphids, V. Raggi and G. Ricciardelli d'Albore and D. Donnini of Perugia Universty for identification of fungi, pollens and plants respectively. We are grateful to A. Mommi for photographic service, L. Bartoli and D. Fortini for their technical help during the field work and C. Bennett Gillies for editing and revising the English text.

\section{REFERENCES}

Andersen G.L. \& Lindow S.E. 1985: Biological control of Carduus pycnocephalus with Alternaria sp. Proc. VI Int. Symp. Biol. Cont. Weeds. pp. 593-600.

Blackman R.L. 1967: The effects of different aphid foods on Adalia bipunctata L. and Coccinella 7-punctata L. Ann. Appl. Biol. 59: 207-219.

FERRAN A. \& DiXON A.F.G. 1993: Foraging behaviour of ladybird larvae (Coleoptera: Coccinellidae). Eur. J. Entomol. 90: 383-402.

Formusoh E.S. \& WILDE G.E. 1993: Preference and development of two species of predatory Coccinellids on the Russian wheat aphid and greenbug biotype (Homoptera: Aphididae) $J$. Agric. Entomol. 10: 65-70.

Goidanich G. 1964: Manuale di Patologia Vegetale. Vol. II. Edagricole, Bologna.

HodeK I. 1956: The influence of Aphis sambuci L. as prey of the ladybird beetle Coccinella septempunctata L. Věst. Čs. Spol. Zool. 20: 62-74.

HodeK I. 1962: Essential and alternative food in insects. $11^{\text {th }}$ Int. Congr. Entomol., Vienna 1960, 2: 696-697. 
HoDeK I. 1996: Dormancy. In Hodek I. \& Honěk A.: Ecology of Coccinellidae. Kluwer, Dordrecht, pp. 239-318.

HoNĚK A. 1982: The distribution of overwintered Coccinella septempunctata (Col. Coccinellidae) adults in agricultural crops. Z. Angew. Entomol. 94: 311-319.

HONĚK A. 1985: Activity and predation of Coccinella septempunctata adults in the field (Col. Coccinellidae). Z. Angew. Entomol. 100: 399-409.

Krafsur E.S, Obrycki J.J. \& Harwood J.D. 2005: Comparative genetic studies of native and introduced Coccinellidae in North America. Eur. J. Entomol. 102: 469-474.

Ialongo M.T., Tedeschi S. \& Pecora P. 1983: Una popolazione di Puccinia suaveolens (Pers.) Rostr. specifica per il Cirsium arvense (L.) Scop. Ann. Ist. Sper. Patol. Veget. 8: 81-87

IPERTI G. 1965: Contribution à l'étude de la specificité chez les principales coccinelles aphidiphages des Alpes-Maritimes et des Basses-Alpes. Entomophaga 10: 159-178.

KuZNETSOV V.N. 1975: Fauna and ecology of coccinellids (Coleoptera, Coccinellidae) in Primorye region. Tr. Biol. Pochv. Inst. 28: 3-24.
Mills N.J. 1981: Essential and alternative foods for some British Coccinellidae (Coleoptera). Entomol. Gaz. 32: 197-202.

OBRYCKi J.J. \& ORR C.J. 1990: Suitability of three prey species for Nearctic population of Coccinella septempunctata, Hippodamia variegata and Propylea quatuordecimpunctata (Coleoptera: Coccinellidae). J. Econ. Entomol. 83: 1292-1297.

SavoIsKaya G.I. 1983: Kokcinellidy. Izdatelstvo Nauka Kazakhskoi SSR, Alma-Ata, 246 pp. (in Russian).

SCHAEFER P.W. \& Dysart R.J. 1988: Palearctic aphidophagous coccinellids in North America. In Niemczik E. \& Dixon A.F.G. (eds): Ecology and Effectiveness of Aphidophaga. SPB Acad. Publ., The Hague, pp. 99-103.

TriLtsch H. 1997: Gut contents in field sampled adults of Coccinella septempunctata (Col.: Coccinellidae). Entomophaga 42: 125-131.

ZHANG Z.Q. 1992: The natural enemies of Aphis gossypii Glover (Hom., Aphididae) in China. J. Appl. Entomol. 114: 251-262.

Received October 18, 2004; revised and accepted April 4, 2005 